\title{
Quality characteristics of spray-dried powders of Pueraria thunbergiana extracts with added forming agents
}

\author{
Jung-Min Kim ${ }^{1}$, Kwang-Sup Youn ${ }^{1,2 *}$ \\ ${ }^{1}$ Department of Food Science and Technology, Daegu Catholic University, Gyeongsan 38430, Korea \\ ${ }^{2}$ Institute of Food Science and Technology, Daegu Catholic University, Gyeongsan 38430, Korea
}

\section{부형제 종류에 따른 분무건조 칡분말의 품질특성}

\author{
김정민 ${ }^{1} \cdot$ 윤광섭 ${ }^{1,2 *}$ \\ ${ }^{1}$ 대구가톨릭대학교 식품공학과, ${ }^{2}$ 대구가톨릭대학교 식품과학연구소
}

\begin{abstract}
This study was designed to investigate the quality characteristics of spray-dried powders from Pueraria thunbergiana extract with added forming agents ( $\beta$-cyclodextrin (CD), dextrin ( $\mathrm{DE}=10$ and $\mathrm{DE}=20)$, and gum arabic (GA); 20\% of each forming agent was added). The moisture contents of the powders were not affected by the addition of forming agents. Highest the total sugar content was observed in the spray-dried powder with $D E=10$. The color intensities $\left(a^{*}, b^{*}\right.$ values) were higher in the spray-dried powders than those in the freeze-dried powders. The water absortion index of the powder with $\mathrm{DE}=10$ was the lowest among the powders with added forming agents. The water solubility indexes of the spray-dried powders were higher than those of the freeze-dried powders. Lowest dynamic angle was observed for the spray-dried powder with GA. The polyphenol and flavonoid contents in the spray-dried powders were significantly higher than those of freeze-dried powders, and the highest DPPH radical scavenging ability was found in the spray-dried powder with added GA $(1 \mathrm{mg} / \mathrm{mL})$. SOD-like activity was not affected by the addition of forming agents. The activity of alcohol dehydrogenase (ADH) increased significantly in the presence of CD, but that of aldehyde dehydrogenase (ALDH) was not affected by the forming agent. Based on these results, the spray-dried powder with CD affected the desired quality characteristics and was found to be suitable for applications in food industry.
\end{abstract}

Key words : Pueraria thunbergiana, spray drying, forming agents, quality characteristics

\section{서 론}

칡(Pueraria thunbergiana)은 콩과의 덩굴성 다년식물로 서 한국, 중국, 만주, 일본 및 동남아시아 각지에서 자생하고 있다. 예로부터 칡은 아시아에서 중요한 약용식물로 사용 되어 왔으며, 칡의 뿌리를 생약명으로는 갈근이라 하여, 껍질을 제거한 뿌리를 절편으로 건조한 것을 이용한다(1).

*Corresponding author. E-mail : ksyoun@cu.ac.kr Phone : 82-53-850-3209, Fax : 82-53-850-3209

Received 15 May 2019; Revised 10 June 2019; Accepted 24 June 2019.

Copyright (c) The Korean Society of Food Preservation. All rights reserved.
뿌리는 약 16-19\%가 전분으로 구성되어 있으며(2), 생리활 성 물질인 isoflavone 유도체인 daidzin 및 그 aglycon인 daidzein과 puerarin 등을 함유하고, saponin, flavonoids 성분 이 순환기 계통에 대한 작용, 혈당강화 작용, 진정작용, 담즙 과 위액의 분비증가 등에 효과적인 것으로 알려져 있다(3). 특히 알코올성 질병의 치료 즉, 항음주 및 해독약물로서 유용하며, Lee(4)의 연구에 따르면 갈근의 catechin에 의한 알코올성 간손상 치료효과를 보고하였다. 체내에 들어온 알코올은 간이나 몸의 다른 기관과 부위로 운반되어 alcohol dehydrogenase $(\mathrm{ADH})$ 에 의해 acetaldehyde로 전환되며, 그 다음 acetaldehyde dehydrogenase(ALDH)에 의해 acetic acid 로 전환되어 소변이나 $\mathrm{CO}_{2}$ 로 배설된다. 우리 몸에 치명적 인 손상을 주는 것은 알코올 그 자체보다도 산화과정에서 
생성된 acetaldehyde로 심혈관계에 작용하여 급성 증상을 나타나게 하며, 체내의 거의 모든 기관을 손상시키고 특히 간조직의 구조와 기능에 치명적인 손상을 유발한다 $(5,6)$. 한편 칡은 다양한 기능성과 약리 작용에도 불구하고 계절적 한계성과 짧은 저장기간, 갈변 등의 원인으로 원료 그대로 관리하는 것이 어려워 칡의 사용이 제한적이다(7). 따라서 칡은 건조한 갈근이나 칡 추출물을 첨가한 건강기능성 식품 및 가공 식품이 개발되어 시판되고 있으며, 칡 전분을 첨가 한 식빵(8), 국수(9), 칡가루를 첨가한 떡(10) 등 가공식품에 적용하기 위한 다양한 연구가 진행되고 있다. 또한 건조 제형가공 방법을 적용한 제품들이 식품시장의 요구에 따라 출시되고 있으며, 그 중 건조분말은 휴대가 간편하고 용해 성이 우수한 장점으로 분말을 이용한 과립, 타블렛 등의 다양한 제품이 제조되고 있다(11). 이처럼 다양한 기능을 함유하고 있는 칡의 품질 및 생리활성에 관한 연구는 다수 진행된 바 있으나 추출물의 건조공정에 따른 품질특성에 관한 연구는 거의 전무한 실정이며 건조분말의 제조 공정 개선과 품질 향상에 관한 연구가 필요한 실정이다.

분무건조법은 미세캡슐화를 만드는 상업화된 방법 중 가장 보편화 된 것으로 그 생산량도 가장 많아서 여러 분야 에서 다양한 목적으로 이용되고 있다(12). 분무건조법의 장점은 비용이 저렴하며 최종산물의 안정성이 좋고 대량으 로 계속적인 생산이 가능하여 다른 건조방식에 비해 용해 성, 유동성이 좋은 구상 분말 제품을 제조할 수 있다(13,14). 식품에 이용되는 미세캡슐의 피막물질은 반드시 식용가능 하며, 용해가 뛰어나고 유화성이 높아야 하며, 또한 가격이 낮아 경제적이어야 한다. 전통적으로 널리 이용된 것으로 는 gum arabic을 비롯한 gum류, 변형되거나 수화된 전분류, cyclodextrin을 비롯한 신소재 polymer 등의 다당류이다 (15).

Cyclodextrin(CD)은 전분에 효소(cycloldextrin glucanotransferase; CGTase)를 작용시켜 얻어진 환상구조 의 물질로 강한 포접능을 가져 향기를 보호할뿐만 아니라 산소, 열, 빛에 대한 안정성을 강화시키는 등의 기능이 있어 다방면에서 사용되고 있다(16). 또한, dextrin류는 흡습성이 낮고, 분산성이 우수한 것이 특징이고 감미가 없으며, gum arabic은 아카시아 나무로부터 생산되는데 용해도가 높고 유화특성과 피막형성능력이 좋아 미세캡슐화에 널리 이용 되고 있고, 낮은 $\mathrm{pH}$ 에서도 안정하며 결착력이 뛰어나 피막 형성과 표면활성의 특징을 지니며, 용해도가 높지만 특유 의 냄새와 색이 있는 것이 단점이다 $(17,18)$.

따라서 본 연구에서는 다양한 생리활성을 가지고 있는 칡의 이용가치를 향상시키고자 부형제로 cyclodextrin, 당 량이 다른 dextrin(DE=10-20) 및 gum arabic의 첨가에 따른 칡 추출물의 품질특성을 검토하여 적합한 부형제 및 제형가 공 활용을 위한 기초자료를 제공하고자 하였다.

\section{재료 및 방법}

재 료

본 실험에서 사용된 칡은 강원도 홍천에서 2017년 12월 채취한 생 칡을 구매하여 사용하였으며, 흙과 먼지 등의 이물질을 제거하여 $5-10 \mathrm{~cm}$ 길이로 절단한 후 건조하여 $4^{\circ} \mathrm{C}$ 에서 보관하면서 사용하였다.

\section{칡 추출물 제조}

칡 추출물의 제조는 절단한 칡 $2 \mathrm{~kg}$ 에 6 배의 증류수를 가하여 압력 한약추출기(KSNP B1130, kyungseo e\&p, Incheon, Korea)를 사용해 $105^{\circ} \mathrm{C}$ 에서 6시간 추출하였다. 추 출액은 여과지에 걸러 불순물을 제거한 뒤 회전 감압농축기 (N-N series, Eyela, Tokyo, Japan)를 이용해 $60^{\circ} \mathrm{C}$ 에서 최종 농도가 $11{ }^{\circ} \mathrm{Brix}$ 가 될 때까지 감압 농축하여 제조하였다.

\section{건조 분말 제조}

부형제는 콘프로덕츠 코리아(Corn Products Korea Inc., Seoul, Korea)에서 구입하여 사용하였으며 $\beta$-cyclodextrin $(\mathrm{CD}), \operatorname{dextrin}(\mathrm{DE}=10), \operatorname{dextrin}(\mathrm{DE}=20)$ 및 gum $\operatorname{arabic}(\mathrm{GA})$ 을 사용하였다. 칡 농축액 $500 \mathrm{~mL}$ 에 부형제를 각각 $20 \%$ 씩 첨가하고 homogenizer(RW20DZM-N, IKA ${ }^{\circledR}$, Freiburg, Germany) 를 이용하여 $9,000 \mathrm{rpm}$ 에서 10 분간 균질화 하였 다.

균질된 액은 분무건조기(KL-8, Seogang Engineering Co., Ltd., Cheonan, Korea)를 이용하여 칡분말을 제조하였으며, 분무건조 조건은 inlet temperature $140-150^{\circ} \mathrm{C}$, oulet temperature $100-110^{\circ} \mathrm{C}$ 로 설정하였고, pump speed $10-12$ $\mathrm{mL} / \mathrm{min}$ 로 조절하였다. 대조 실험구로는 부형제를 첨가하 지 않은 동결건조 분말을 사용하여 비교하였다.

\section{수분 및 색도}

수분함량은 적외선 수분측정기(HG53 Halogen Moisture Analyzer, Mettler-Toledo, Zurich, Switzerland)를 사용하여 측정하였으며, 색도는 색차계(CR-300, Minolta Co., Osaka, Japan)로 측정하였으며, 밝기를 나타내는 $\mathrm{L}^{*}$ (lightness), 적 색도를 나타내는 $\mathrm{a}^{*}$ (redness), 황색도를 나타내는 $\mathrm{b}^{*}$ (yellowness) 를 측정하였다.

\section{총당 함량}

총당 함량은 phenol-sulfate acid법(19)에 따라 측정하였 다. 시료 $1 \mathrm{~mL}$ 에 $5 \%$ phenol $1 \mathrm{~mL}$ 와 sul-furic acid $5 \mathrm{~mL}$ 를 가한 후 교반하여 발색시킨 다음 20 분 방치 후 spectrophotometer(UV1800, shimadzu, Kyoto, Japan)을 이용 하여 $470 \mathrm{~nm}$ 에서 흡광도를 측정하였고, glucose 표준물질 검량선에 대입하여 함량을 산출하였다. 
수분흡수지수(WAI) 및 수분용해지수(WSI) 측정

수분흡수지수(water absorption index, WAI) 및 수분용해 지수(water solubility index, WSI) 측정은 Phillips 등(20)의 방법을 변형하여 측정하였다. 건조분말 $0.5 \mathrm{~g}$ 에 $20 \mathrm{~mL}$ 증류 수를 첨가하여 $3,000 \mathrm{rpm}$ 에서 20 분간 원심분리한 후 침전물 은 수분흡수지수로 계산하였으며, 상등액은 미리 무게를 구한 수기에 분리하여 $105^{\circ} \mathrm{C}$ 에서 4 시간 동안 건조시킨 고형 분을 수분용해지수로 사용하여 아래와 같이 계산하였다.

$$
\begin{aligned}
& \text { 수분흡수지수 }(W A I)=\frac{\text { 침전물의 양 }}{\text { 시료의 양 }} \\
& \text { 수분용해지수 }(W S I, \%)=\frac{\text { 상등액고형분의 양 }}{\text { 시료의양 }} \times 100
\end{aligned}
$$

\section{안식각}

안식각은 시료의 흐름성을 알아 볼 수 있는 쌓임각의 방법(21)을 변형하여 측정하였다. 시료 $20 \mathrm{~g}$ 을 고정시킨 깔때기에 넣고 일시에 내려오도록 진동시켰다. 평면 위로 낙하되어 건조분말이 원뿔모양으로 퇴적시킨 후 원주의 모선을 그리고, 10 군데를 지정하여 평균 반지름을 측정하 였고, 깔때기와 수평면과의 높이를 측정하여 수평면과 이 루는 각을 측정하였으며 다음 식을 이용하여 안식각을 계산 하였다.

Angle of repose $(\cot a)=r($ 원주의 반지름 $) / h($ 깔때기와 수 평면이 이루는 높이)

\section{폴리페놀 함량 측정}

Dewanto 등의 방법(22)에 따라 시료 $100 \mu \mathrm{L}$ 에 $2 \%$ sodium carbonate $2 \mathrm{~mL}$ 과 50\% Folin-Ciacalteu reagent $100 \mu \mathrm{L}$ 을 가한 후 $720 \mathrm{~nm}$ 에서 흡광도를 측정하였으며 gallic acid(Sigma-Aldri-ch Co., St. Louis, MO, USA)의 검량선에 의하여 함량을 산출하였다.

\section{플라보노이드 함량 측정}

Abdel-Hameed의 방법(23)에 따라 시료 $100 \mu \mathrm{L}$ 에 $5 \%$ sodium nitrite $0.15 \mathrm{~mL}$ 을 가한 후 $25^{\circ} \mathrm{C}$ 에서 6 분간 방치한 다음 $10 \%$ aluminium choloride $0.3 \mathrm{~mL}$ 를 가하여 $25^{\circ} \mathrm{C}$ 에서 5 분간 방치하였다. 다음 $1 \mathrm{~N} \mathrm{NaOH} 1 \mathrm{~mL}$ 를 가하고 vortex상 에서 가한 후 $510 \mathrm{~nm}$ 에서 흡광도를 측정하였으며 rutin hydrate(Acros-Organics, New jersey, NJ, USA)의 검량선에 의하여 함량을 산출하였다.

\section{$\mathrm{DPPH}$ radical 소거활성 측정}

Blois의 방법(24)에 따라 시료 $0.2 \mathrm{~mL}$ 에 $0.4 \mathrm{mM}$ $\mathrm{DPPH}(1,1$ diphenyl-2-picryl-hydrazyl)용액 $0.8 \mathrm{~mL}$ 를 가하여 10 분간 방치 한 다음 $525 \mathrm{~nm}$ 에서 흡광도를 측정하였으며 계산식, DPPH radical scavening activity(\%) = $100-[(\mathrm{OD}$ of sample/OD of control) $\times 100]$ 에 의하여 활성도를 산출하였 다.

\section{Superoxide dismutase 유사활성 측정}

Marklund와 Marklund의 방법(25)에 따라 시료 $200 \mu \mathrm{L}$ 에 $\mathrm{pH}$ 8.5로 조정한 tris- $\mathrm{HCl}$ buffer 용액 $3 \mathrm{~mL}$ 와 $7.2 \mathrm{mM}$ pyrogallol $200 \mu \mathrm{L}$ 을 가하고 $25^{\circ} \mathrm{C}$ 에서 10 분간 반응시킨 후 $1 \mathrm{~N} \mathrm{HCl} 1 \mathrm{~mL}$ 를 가하여 반응을 정지시키고 $420 \mathrm{~nm}$ 에서 흡광도를 측정하였으며 계산식, SOD-like $\operatorname{activity}(\%)=$ 100 - [(OD of sample/OD of control $) \times 100]$ 에 의하여 활성을 산출하였다.

\section{$\mathrm{ADH}$ 활성 측정}

$\mathrm{ADH}$ (alcohol dehydrogenase)의 활성 측정은 $\mathrm{ADH}$ quantification assay kit(Megazyme, Wicklow, Ireland)를 사 용하여 Megazyme protocol에 따라 측정하였다(26). 즉, 증 류수 $1 \mathrm{~mL}$, buffer plus sodium azide( $0.02 \% \mathrm{w} / \mathrm{v}) 0.1 \mathrm{~mL}$, $\mathrm{NAD}+$ solution $0.1 \mathrm{~mL}$ 와 $20 \%$ 에탄올 $10 \mu \mathrm{L}$ 를 혼합하여 시료 $20 \mu \mathrm{L}$ 를 가한 후 실온에서 2 분동안 반응시킨 후 340 $\mathrm{nm}$ 에서 기본흡광도(A1)를 측정하였다. 이후 $\mathrm{ADH} 10 \mu \mathrm{L}(1$ assay unit)를 가하고 실온에서 5분 동안 반응시킨 후 340 $\mathrm{nm}$ 에서 $\mathrm{NADH}$ 생성 때문에 증가한 흡광도(A2)를 측정하 였으며 알코올 분해효소의 활성은 변화된 흡광도(A2-A1) 를 기반으로 시료를 첨가하지 않은 대조구에 대한 상대적인 활성 $(\%)$ 으로 나타내었다.

\section{$\mathrm{ALDH}$ 활성 측정}

$\mathrm{ALDH}$ (acetaldehyde dehydrogenase)의 활성 측정은 ALDH quantification assay kit(Megazyme, Wicklow, Ireland) 를 사용하여 Megazyme protocol에 따라 측정하였다(26). 즉, 증류수 $1 \mathrm{~mL}$, buffer plus sodium azide( $0.02 \% \mathrm{w} / \mathrm{v}) 0.1$ $\mathrm{mL}, \mathrm{NAD}+$ solution $0.1 \mathrm{~mL}$ 과 증류수에 녹인 $20 \%$ 아세트알 데하이드 $10 \mu \mathrm{L}$ 를 혼합하여 시료 $20 \mu \mathrm{L}$ 별로 가한 후 실온에 서 2 분 동안 반응시킨 후 $340 \mathrm{~nm}$ 에서 기본흡광도를 측정하 였다. 이후 ALDH $25 \mu \mathrm{L}(1$ assay unit)를 가한 후 실온에서 5 분 동안 반응시킨 후에 $340 \mathrm{~nm}$ 에서 $\mathrm{NADH}$ 생성 때문에 증가한 흡광도를 측정하였다. $\mathrm{ALDH}$ 의 활성은 변화된 흡광 도를 기반으로 시료를 첨가하지 않은 대조구에 대한 상대적 인 활성 $(\%)$ 으로 나타내었다.

\section{통계처리}

모든 실험은 3회 반복으로 행하여 평균치와 표준편차로 나타내었고, 유의성 검증은 SPSS 12(SPSS Inc., Chicago, IL, USA) software package program을 이용하여 Duncan's multiple range test를 행하였다. 


\section{결과 및 고찰}

\section{수분 함량, 총 당 함량 및 색도}

칡 추출물의 동결건조 및 분무건조, 부형제 종류 $[\beta$ -cyclodextrin(CD), dextrin( $\mathrm{DE}=10)$, dextrin( $\mathrm{DE}=20)$, gum $\operatorname{arabic}(\mathrm{GA})]$ 첨가에 따른 수분함량 및 색도를 측정한 결과는 Table 1 과 같다. 동결건조 분말은 $4.06 \%$ 를 나타내어 분무건 조 분말 2.54-3.14\%에 비해 높은 함량이 나타났다. 이는 분무건조 분말 제조를 위한 분무건조 공정에서 가열 온도가 증가하면 열전달 효율성의 증가로 인해 수분함량이 감소한 다는 보고와 일치하였으며(27), 부형제 종류에 따른 차이는 크게 나타나지 않았다.

칡 추출 분말의 총당 함량은 동결건조, 분무건조에서 각 각 $15.84 \%, 16.97-18.72 \%$ 로 분무건조에서 높게 나타내었지 만 큰 차이는 나타나지 않았다. 부형제 종류에 따라서는 차이가 거의 나타나지 않았으나, 부형제로 사용된 $\beta$ -cyclodextrin, dextrin, gum arabic 자체에 존재하는 당류에 의하여 부형제를 사용하지 않은 분말에 비해 높은 총 당 함량을 나타낸 것으로 생각되며, Park 등(28)은 노루궁뎅이 버섯 추출물을 이용한 과립과 타블렛 제조 시 부형제로 사용한 탄수화물 제제로 인하여 총당 함량이 증가한다고 보고한 결과와 일치하였다.
분말의 외관상 품질을 결정하는 요소 중 하나인 색도의 경우 동결건조 분말의 $\mathrm{L}^{*}$ 값, $\mathrm{a}^{*}$ 값 및 $\mathrm{b}^{*}$ 값이 각각 44.35 , $2.21,7.84$ 를 나타내었으며, 분무건조 분말의 경우 $\mathrm{L}^{*}$ 값은 40.68-41.98을 나타내었으며, $\mathrm{a}^{*}$ 값 및 $\mathrm{b}^{*}$ 값의 경우 2.93-3.17 및 9.36-11.21으로 분무건조 분말이 동결건조 분 말에 비해 $\mathrm{a}^{*}$ 값 및 $\mathrm{b}^{*}$ 값이 높게 나타났다. 이러한 결과는 온도의 영향에 따른 갈변 현상으로 인한 결과로 판단되며, Kim 등(29)이 보고한 건조방법에 따른 양파분말의 품질특 성에 관한 연구에서 건조온도가 높을수록 $\mathrm{L}^{*}$ 값이 감소하 고, $a^{*}$ 값 및 $b^{*}$ 값이 증가한다는 결과와 유사하였다.

수분흡수지수(WAI), 수분용해지수(WSI), 안식각

건조 분말의 경우 수분흡수지수와 용해지수는 식품산업 활용 측면에서 중요한 가공적성 요인으로 알려져 있다(30). 건조 방법 및 부형제 종류에 따른 칡 추출물 분말의 수분흡 수지수와 용해지수, 그리고 안식각을 비교한 결과는 Table 2 와 같다. 칡 추출분말의 수분흡수지수(WAI)는 동결건조 분말에서 0.85 로 가장 높은 지수를 나타내었으며 분무건조 분말에서 0.31-0.80의 범위를 나타내어 분무건조 시 낮은 흡수지수를 보였다. 또한 부형제를 달리하여 제조한 분무 건조 분말의 흡수지수는 $\mathrm{GA}>\mathrm{CD}>\mathrm{DE} 20>\mathrm{DE} 10$ 순으로 $\mathrm{DE} 10$ 에서 가장 낮은 수치를 나타내었고 $\mathrm{GA}$ 에서 가장 높은

Table 1. Moisture content, total sugar content, color of spray-dried powders prepared with Pueraria thunbergiana extracts

\begin{tabular}{cccccc}
\hline \multirow{2}{*}{ Samples $^{1}$} & Moisture contents $(\%)$ & Total sugar $(\%)$ & \multicolumn{3}{c}{ Color value } \\
\cline { 3 - 5 } & & & Lightness $\left(\mathrm{L}^{*}\right)$ & Redness $\left(\mathrm{a}^{\star}\right)$ & Yellowness $\left(\mathrm{b}^{\star}\right)$ \\
\hline FD & $\left.4.06 \pm 0.04^{\mathrm{a} 2}\right)$ & $15.84 \pm 0.04^{\mathrm{c}}$ & $44.35 \pm 0.42^{\mathrm{a}}$ & $2.21 \pm 0.14^{\mathrm{c}}$ & $7.84 \pm 0.21^{\mathrm{d}}$ \\
SD & $2.73 \pm 0.21^{\mathrm{c}}$ & $16.97 \pm 0.02^{\mathrm{b}}$ & $40.75 \pm 0.39^{\mathrm{c}}$ & $3.03 \pm 0.08^{\mathrm{b}}$ & $9.36 \pm 0.28^{\mathrm{c}}$ \\
CD & $2.54 \pm 0.12^{\mathrm{c}}$ & $18.27 \pm 1.01^{\mathrm{a}}$ & $41.60 \pm 0.31^{\mathrm{b}}$ & $3.04 \pm 0.03^{\mathrm{b}}$ & $10.84 \pm 0.26^{\mathrm{ab}}$ \\
DE10 & $3.14 \pm 0.11^{\mathrm{b}}$ & $18.72 \pm 0.13^{\mathrm{a}}$ & $41.98 \pm 0.10^{\mathrm{b}}$ & $3.21 \pm 0.03^{\mathrm{a}}$ & $11.21 \pm 0.14^{\mathrm{a}}$ \\
DE20 & $3.01 \pm 0.00^{\mathrm{b}}$ & $18.45 \pm 0.10^{\mathrm{a}}$ & $40.68 \pm 0.44^{\mathrm{c}}$ & $2.93 \pm 0.02^{\mathrm{b}}$ & $9.66 \pm 0.46^{\mathrm{c}}$ \\
GA & $3.07 \pm 0.11^{\mathrm{b}}$ & $18.14 \pm 0.25^{\mathrm{a}}$ & $41.72 \pm 0.22^{\mathrm{b}}$ & $3.17 \pm 0.06^{\mathrm{a}}$ & $10.33 \pm 0.45^{\mathrm{b}}$ \\
\hline
\end{tabular}

${ }^{11} \mathrm{FD}$; freeze-dried powder from Pueraria thunbergiana extracts, SD; spray-dried powder from Pueraria thunbergiana extracts, CD; spray-dried powder added $20 \% \beta$-cyclodextrin, $\mathrm{DE}=10$; spray-dried powder added 20\% dextrin( $\mathrm{DE}=10), \mathrm{DE}=20$; spray-dried powder added $20 \%$ dextrin( $\mathrm{DE}=20)$, GA; spray-dried powder added $20 \%$ gum arabic

${ }^{2)}$ Values are mean $\pm \mathrm{SD}$ of triplicate determinations. Different superscripts within a column indicate significant differences $(\mathrm{p}<0.05)$.

Table 2. Water absorption index(WAI), water solubility index(WSI) and dynamic angle of spray-dried powders prepared with Pueraria thunbergiana extracts

\begin{tabular}{cccc}
\hline Samples $^{1)}$ & WAI & WSI $(\%)$ & Dynamic angle $\left(^{\circ}\right)$ \\
\hline FD & $0.85 \pm 0.03^{\mathrm{a} 2)}$ & $93.95 \pm 0.88^{\mathrm{c}}$ & $18.38 \pm 0.74^{\mathrm{a}}$ \\
SD & $0.31 \pm 0.05^{\mathrm{b}}$ & $97.84 \pm 0.78^{\mathrm{ab}}$ & $16.43 \pm 0.89^{\mathrm{b}}$ \\
CD & $0.53 \pm 0.17^{\mathrm{b}}$ & $98.95 \pm 0.70^{\mathrm{a}}$ & $14.71 \pm 0.85^{\mathrm{c}}$ \\
DE10 & $0.49 \pm 0.11^{\mathrm{b}}$ & $98.74 \pm 0.59^{\mathrm{a}}$ & $13.30 \pm 0.39^{\mathrm{d}}$ \\
DE20 & $0.51 \pm 0.03^{\mathrm{b}}$ & $98.71 \pm 0.85^{\mathrm{a}}$ & $15.09 \pm 1.04^{\mathrm{c}}$ \\
GA & $0.80 \pm 0.25^{\mathrm{a}}$ & $97.23 \pm 0.16^{\mathrm{b}}$ & $10.62 \pm 0.70^{\mathrm{e}}$ \\
\hline
\end{tabular}

${ }^{1)} \mathrm{FD}$; freeze-dried powder from Pueraria thunbergiana extracts, SD; spray-dried powder from Pueraria thunbergiana extracts, CD; spray-dried powder added $20 \% \beta$-cyclodextrin, $\mathrm{DE}=10$; spray-dried powder added $20 \%$ dextrin( $\mathrm{DE}=10), \mathrm{DE}=20$; spray-dried powder added $20 \%$ dextrin( $\mathrm{DE}=20$ ), GA; spray-dried powder added $20 \%$ gum arabic

${ }^{2)}$ Values are mean $\pm \mathrm{SD}$ of triplicate determinations. Different superscripts within a column indicate significant differences $(\mathrm{p}<0.05)$. 
수치를 나타내었다. 이는 DE에 따른 흡습성 등 부형제의 물리화학적 특성의 차이로 $\mathrm{DE}$ 값이 낮을수록 흡습성도 함께 낮아지는 특성에 기인된 결과로 사료되며(31), Kim 등(32)의 블랜칭 처리 및 부형제 종류에 따른 곰취 착즙액 분무건조 분말에서 $\mathrm{DE}$ 값이 낮을수록 흡습지수가 낮아진 다고 보고하여 본 연구결과와 일치하였다. 또한 $\mathrm{Han}$ 과 Youn(33)의 습식분쇄하여 분무건조한 초미세 분말 칼슘의 품질특성에서 gum arabic을 첨가하여 제조한 액상초미세칼 슘 분무건조 분말이 가장 많이 흡습하는 것과 유사한 결과 를 나타내었다.

수분용해지수는 동결건조 분말에서 $93.95 \%$ 로 가장 낮게 나타내었으며 분무건조 분말에서 97.23-98.95\%로 나타나 우수하였다. 용해도의 경우 분말에서 중요한 품질특성으로 간주됨에 따라 $\beta$-cyclodextrin 및 dextrin( $\mathrm{DE}=10-20)$ 을 부형 제로 활용할 경우 용해도 증가에 유효할 것으로 판단된다.

안식각은 자유낙하한 분말이 바닥에 떨어지면서, 퇴적층 이 차지하는 최대경사의 수평면과 이루는 각도로 안식각이 작을수록 분체의 유동성이 좋은 것으로 판단할 수 있는데, 이를 통해 분말의 caking 정도를 간접적으로 측정할 수 있다 (34). 동결건조 분말의 안식각은 $18.38^{\circ}$, 부형제를 첨가하지 않은 분무건조 분말의 안식각은 $16.43^{\circ}$ 로 나타나 분무건조 분말의 안식각이 낮음을 확인하였다. 안식각이 작을수록 입자가 더 멀리 넓게 퍼지는 것을 의미한다(35). 따라서 부형제별 분무건조 분말의 안식각을 비교분석한 결과 gum arabic을 사용한 분무건조 분말이 10.62 로 가장 낮은 안식각 을 나타내어 유동성을 증대시킨 제품을 생산하거나 산업적 활용에 우수할 것으로 사료된다.

\section{총 폴리페놀 및 플라보노이드 함량}

총 폴리페놀 함량은 동결건조와 분무건조에서 $\mathrm{g}$ 당 각각 $11.28 \mathrm{mg}$ 과 $13.52-17.41 \mathrm{mg}$ 으로 분무건조가 동결건조에 비하여 높은 함량을 나타내었다. 분무건조 분말의 경우 부 형제를 사용하지 않은 분말이 $17.41 \mathrm{mg}$ 로 가장 높게 나타났 으며, 부형제 종류에 따라서는 $\mathrm{GA}$ 에서 가장 높게 나타내었 으나 부형제 종류에 따라 큰 차이는 나타나지 않았다. 총 플라보노이드 함량에서도 마찬가지로 동결건조와 분무건 조에서 $\mathrm{g}$ 당 각각 $6.91 \mathrm{mg}, 10.17-11.25 \mathrm{mg}$ 로 분무건조가 유의적으로 높은 함량을 나타내었지만 부형제 종류에 따른 분무건조 분말간의 차이는 크지 않았다. 이는 Lee 등(36)의 감국, 산국 및 구절초꽃 분말 차의 총 폴리페놀 및 플라보노 이드 함량을 측정한 결과 부형제의 종류 및 농도에 따라 유의적인 차이를 나타내지 않은 결과와 유사하였다.

\section{$\mathrm{DPPH}$ 라디칼 소거활성 및 SOD 유사활성}

칡 추출물의 분무건조 및 동결건조한 분말의 $\mathrm{DPPH}$ radical 소거활성 및 superoxide dismutase(SOD) 유사활성을 조사한 결과는 Fig. 1,2 와 같다. DPPH 소거활성의 경우

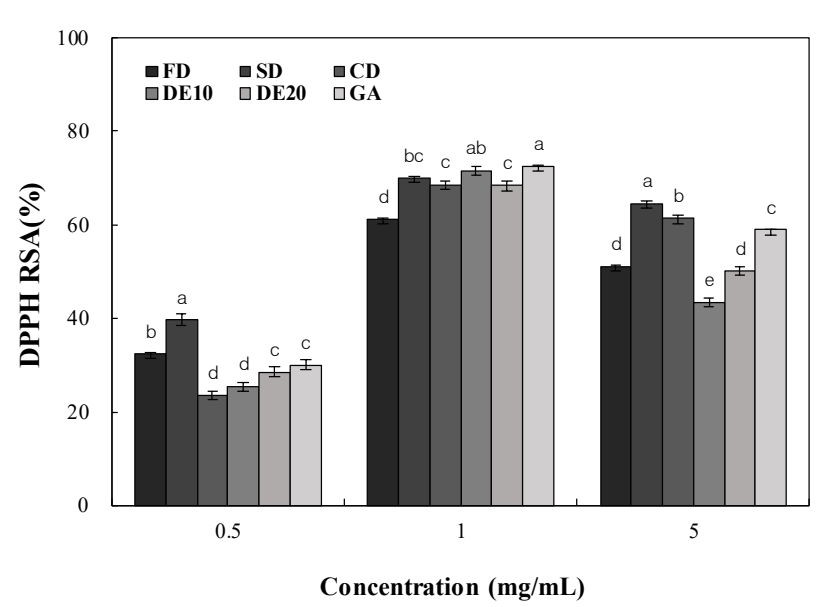

Fig. 1. Electron donating ability of spray-dried powders prepared with Pueraria thunbergiana extracts.

Values are mean $\pm \mathrm{SD}$ of triplicate determinations. Values with different letters on the bar $(\mathrm{a}-\mathrm{e})$ indicate significant differences $(\mathrm{p}<0.05)$.

모든 농도에서 분무건조 분말이 동결건조 분말에 비해 높은 활성을 나타내었으며, 특히 $1 \mathrm{mg} / \mathrm{mL}$ 농도에서 분무건조가 $68.39-72.45 \%$, 동결건조가 $61.18 \%$ 로 분무건조가 동결건조 에 비해 더 높은 DPPH 라디칼 소거활성을 나타내었다. $\mathrm{DPPH}$ 라디칼 소거활성은 분무건조 시 항산화 활성이 증대 되는 현상은 칡 추출물에 존재하는 환원성 물질, 고분자 물질, 라디칼 소거활성을 가지는 물질 등으로 인해 폴리페 놀의 함량이 증가함에 따라 활성 또한 증가한 것으로 판단 된다.

칡 추출물의 분무건조 및 동결건조한 분말의 superoxide dismutase(SOD) 유사활성을 조사한 결과 Fig 2와 같다. $\mathrm{SOD}$ 유사활성은 동결건조 및 분무건조 각각 $13.25 \%$, 13.07-14.37\%로 유사한 활성을 나타내었으며 Kim 등(37)의 해조분말 추출물의 건조방법에 따른 품질 및 항산화

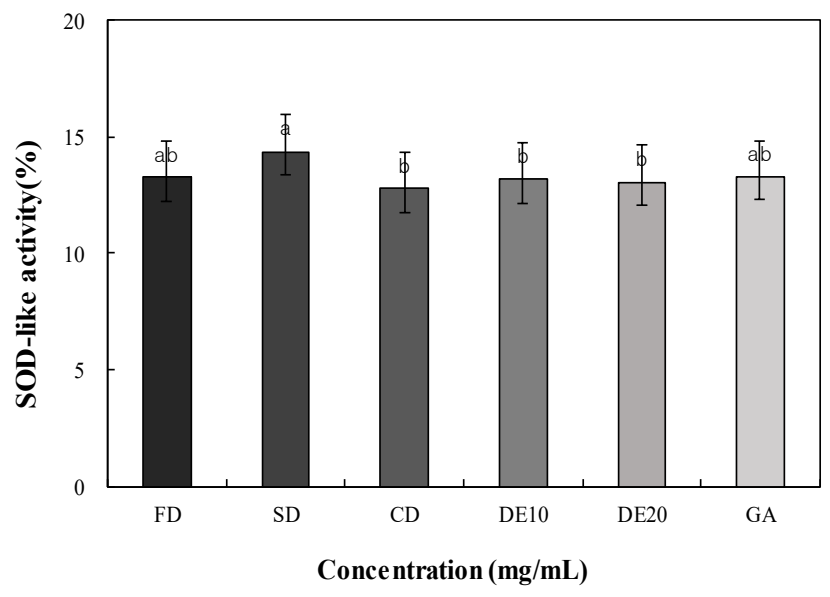

Fig. 2. Superoxide dismutase like activity of spray-dried powders prepared with Pueraria thunbergiana extracts.

Values are mean $\pm \mathrm{SD}$ of triplicate determinations. Values with different letters on the bar $(a-b)$ indicate significant differences $(p<0.05)$. 
특성에서 미역 추출물의 분무 및 동결건조 분말의 $\mathrm{SOD}$ 유사활성이 차이가 나타나지 않은 결과와 일치하였다. SOD 유사활성이란 SOD와 같이 superoxide를 정상의 산소 로 전환시킬 수는 없으나 superoxide의 반응성을 억제하여 생체를 산화적 손상으로부터 보호할 수 있는 주로 phytochemical의 저분자 물질이라고 보고하였다(38). 따라 서 칡 추출물의 SOD 유사활성은 건조 방법 및 부형제 종류 에 따른 영향을 받지 않는다고 사료된다.

Table 3. Total polyphenol and flavonoid contents of spray-dried powders prepared with Pueraria thunbergiana extracts

(mg/mL, dry basis)

\begin{tabular}{ccc}
\hline Samples $^{1)}$ & Polyphenols $\left(\mathrm{mgGAE}^{2} / \mathrm{g}\right)$ & Flavonoids $\left(\mathrm{mgRHE}^{3)} / \mathrm{g}\right)$ \\
\hline FD & $11.28 \pm 0.39^{\mathrm{e})}$ & $6.91 \pm 0.26^{\mathrm{c}}$ \\
SD & $17.41 \pm 0.13^{\mathrm{a}}$ & $10.51 \pm 0.22^{\mathrm{b}}$ \\
CD & $13.81 \pm 0.26^{\mathrm{d}}$ & $11.19 \pm 0.22^{\mathrm{a}}$ \\
DE10 & $13.52 \pm 0.12^{\mathrm{d}}$ & $10.17 \pm 0.51^{\mathrm{b}}$ \\
DE20 & $14.99 \pm 0.10^{\mathrm{c}}$ & $10.33 \pm 0.02^{\mathrm{b}}$ \\
GA & $15.73 \pm 0.17^{\mathrm{b}}$ & $11.25 \pm 0.29^{\mathrm{a}}$ \\
\hline
\end{tabular}

${ }^{1} \mathrm{FD}$; freeze-dried powder from Pueraria thunbergiana extracts, SD; spray-dried powder from Pueraria thunbergiana extracts, CD; spray-dried powder added $20 \% \beta$ -cyclodextrin, $\mathrm{DE}=10$; spray-dried powder added $20 \%$ dextrin( $(\mathrm{DE}=10), \mathrm{DE}=20$; spray-dried powder added 20\% dextrin(DE=20), GA; spray-dried powder added 20\% gum arabic

${ }^{2 \cdot 3}$ Abbreviations: GAE, gallic acid equivalents; RHE, rutin hydrate equivalents.

${ }^{4}$ Values are mean $\pm \mathrm{SD}$ of triplicate determinations. Different superscripts within a column indicate significant differences $(\mathrm{p}<0.05)$.

\section{$\mathrm{ADH}$ 및 $\mathrm{ALDH}$ 활성에 미치는 영향}

칡 추출물의 분무건조 및 동결건조한 분말의 $\mathrm{ADH}$ 및 $\mathrm{ALDH}$ 활성을 조사한 결과는 Table 4와 같다. 체내 알코올 대사 1 차 관여 효소인 $\mathrm{ADH}$ 의 활성 증진 정도를 측정하였으 며, 또한 acetaldehyde 분해에 직접적인 영향을 미치는 효소 인 $\mathrm{ALDH}$ 의 활성에 대하여 조사하였다. $\mathrm{ADH}$ 활성은 동결 건조 분말 $191.49 \%$, 분무건조 분말 $187.01-227.7 \%$ 로 활성 증가를 확인하였다. 부형제를 첨가하지 않은 분무건조 분 말에서 $227.7 \%$ 로 가장 높게 나타났으며 부형제를 첨가한 분말에서는 $\mathrm{CD}>\mathrm{DE} 10>\mathrm{GA}>\mathrm{DE} 20$ 순으로 나타났다. $\mathrm{ALDH}$ 활성은 동결건조, 분무건조 각각 $23.9 \%$, 24.71-27.97\%로 분무건조 분말에서 ALDH 활성 증진 효과 가 더 높게 나타내었으나 유의적인 차이는 나타나지 않았으 며, 또한 부형제 종류에 따른 활성 차이도 나타나지 않았다. 이는 Hong 등(39)의 dextrin과 $\beta$-cyclodextrin이 생체내에서 헛개나무 추출물의 알코올성 손상으로부터 간보호에 미치 는 영향에서 dextrin과 $\beta$-cyclodextrin가 $\mathrm{ADH}$ 및 $\mathrm{ALDH}$ 활 성에 영향을 미치지 않은 결과와 유사하였다.

따라서 $\beta$-cyclodextrin을 부형제로 분무건조한 분말은 $\mathrm{ADH}, \mathrm{ALDH}$ 활성을 증진시키는 제품을 생산할 경우 활성 에 큰 영향을 미치지 않을 것으로 판단되며, 기능성 식품소 재의 부형제로서 유용하리라 사료된다.
Table 4. Alcohol dehydrogenase(ADH) and acetaldehyde dehydrogenase (ALDH) activities of spray-dried powders prepared with Pueraria thunbergiana extracts

\begin{tabular}{ccc}
\hline \multirow{2}{*}{ Samples $^{1)}$} & \multicolumn{2}{c}{ Activity(\%) } \\
\cline { 2 - 3 } & ADH & ALDH \\
\hline FD & $191.49 \pm 6.69^{\mathrm{b}}$ & $23.90 \pm 0.48^{\mathrm{b}}$ \\
SD & $227.70 \pm 6.21^{\mathrm{a}}$ & $27.97 \pm 1.62^{\mathrm{a}}$ \\
CD & $222.64 \pm 7.09^{\mathrm{a}}$ & $27.57 \pm 1.37^{\mathrm{a}}$ \\
DE10 & $192.53 \pm 9.36^{\mathrm{b}}$ & $24.71 \pm 1.21^{\mathrm{b}}$ \\
DE20 & $179.08 \pm 5.61^{\mathrm{c}}$ & $26.03 \pm 0.83^{\mathrm{ab}}$ \\
GA & $187.01 \pm 2.79^{\mathrm{bc}}$ & $25.77 \pm 1.44^{\mathrm{ab}}$ \\
\hline
\end{tabular}

${ }^{1} \mathrm{FD}$; freeze-dried powder from Pueraria thunbergiana extracts, SD; spray-dried powder from Pueraria thunbergiana extracts, CD; spray-dried powder added $20 \% \beta$ -cyclodextrin, $\mathrm{DE}=10$; spray-dried powder added $20 \%$ dextrin( $(\mathrm{DE}=10), \mathrm{DE}=20$; spray-dried powder added $20 \%$ dextrin( $(\mathrm{DE}=20), \mathrm{GA}$; spray-dried powder added $20 \%$

gum arabic
2) Values are mean $\pm \mathrm{SD}$ of triplicate determinations. Different superscripts within a column indicate significant differences $(p<0.05)$.

\section{요 약}

본 연구에서는 다양한 생리활성을 가지고 있는 칡의 이 용가치를 향상시키고자 부형제로 $\beta$-cyclodextrin, 당량이 다 른 dextrin(DE10-20) 및 gum arabic의 첨가에 따른 칡 추출물 분무건조 분말의 품질특성을 비교 분석하였다. 분무건조 분말의 수분함량은 2.54-3.14\%였으며, 총 당 함량은 부형제 를 첨가한 분말에서 증가하였으며, 색도는 분무건조 분말 에서 $\mathrm{L}^{*}$ 값은 낮고, $\mathrm{b}^{*}$ 값과 $\mathrm{a}^{*}$ 값은 높게 나타났다. 수분흡 수지수는 $\mathrm{DE}=10$ 에서 0.49 로 가장 낮았으며, 수분용해지수 는 $\mathrm{CD}$ 에서 $98.95 \%$ 로 가장 높게 나타났다. 안식각은 부형제 를 첨가한 분말에서 감소하는 양상을 보였으며, 부형제 종 류에 따라서는 $\mathrm{DE} 20>\mathrm{CD}>\mathrm{DE} 10>\mathrm{GA}$ 순이었다. 총 폴리페놀 및 플라보노이드 함량은 각각 $13.52-17.41 \mathrm{mg} / \mathrm{g}$, $10.17-11.25 \mathrm{mg} / \mathrm{g}$ 으로 분무건조가 동결건조에 비하여 유의 적으로 높게 나타났고, 부형제 종류에 따라서는 큰 차이가 나타나지 않았으며, SOD 유사활성에서도 $1 \mathrm{mg} / \mathrm{mL}$ 농도에 서 부형제 종류에 따라 13.07-14.37\%로 유의적인 차이를 나타내지 않았다. $\mathrm{ADH}$ 활성은 부형제 종류에 따라 $\mathrm{CD}$ 에서 $222.64 \%$ 로 가장 높게 나타났으며, ALDH는 23.9-27.97\%로 건조방법 및 부형제 종류가 영향을 미치지 않는 것으로 확인하였다. 이러한 결과를 종합해 볼 때, 분무건조 칡분말 제조 시 부형제로 $\beta$-cyclodextrin을 사용하여 용해성, 유동 성 증대 효과 및 천연 추출물 생리활성 기능 보존에도 효과 가 있어 가공적성 및 산업적 활용에 우수할 것으로 사료된 다. 


\section{감사의 글}

본 논문은 2018년도 대구가톨릭대학교 교내연구비 지원 에 의한 것으로 감사드립니다.

\section{References}

1. Choi GH, Kim HJ, Park IJ, Kim BG, Kim HY, Jeong JH, Cho JH (2017) Antioxidative activity of roasted Pueraria lobata root extracts. Korean J Food Preserv, 24, 440-445

2. Suzuki A, Hizukuri S, Takeda Y (1981) Physicochemical studies and kumz starch. Cereal Chem, 58, 286-290

3. Kim JJ, Lee HJ, Yee ST (2012) Effect of Pueraria thunbergiana extracts on the activation of lmmune cells. J Life Sci, 22, 1107-1113

4. Lee CH (1997) Biological effects of korean puerariae radix catechins on the liver function in rats administered with ethanol. J Korean Soc Food Sci Nutr, 2, 138-143

5. Bode C, Kugler V, Bode JC (1987) Endotoxemia in patients with alcoholic and non-alcoholic cirrhosis and in subjects with no evidence of chronic liver disease following acute alcohol excess. J Hepatol, 4, 8-14.

6. Setshedi M, Wands JR, Monte SM (2010) Acetaldehyde adducts in alcoholic liver disease. Oxid Med Cell Longevity, 3, 178-185

7. Kwon YR, Nam S, Jeong DS, Kwon RE, Youn KS (2016) Quality characteristics of Pueraria thunbergiana extracts depending on drying methods. Korean J Food Preserv, 23, 654-659

8. Han G, Hwang SY, Rho S (2013) Quality characteristics of white bread with arrowroot powder. J East Asian Soc Dietary Life, 23, 778-788

9. Lee YS, Lim NY, Lee KH (2000) A study on the preparation and evaluation of dried noodle products made from composite flours utilizing aroowroot starch, Korean J Soc Food Sci, 16, 681-688

10. Gu SY, Lee HG (2001) The sensory and textural characteristics of Chicksulgi. Korean J Food Cookery Sci, 17, 523-532

11. Youn KS (2004) Preparation and quality characteristics of tablet using cheonggukjang powder. J East Asian Soc Dietary Life, 14, 495-500

12. Reinccius GA (1988) Spray-Drying of Food Flavors. Food Technol, 7, 55-66

13. Kim EHJ, Chen XD, Pearce D (2005) Melting characteristics of fat present on the surface of industrial spray-dried dairy powders. Colloids Surf B, 42, 1-8

14. Sano Y (1993) Gas flow behavior in spray dryer. Dry Technol, 11, 697-718

15. Lee SC, Rhim CH, Lee SC (1997) Characteristics of spray dried polysaccharides for microencapsulation. Korean J Food Sci Technol, 29, 1322-1326

16. Shahidi F, Han XQ (1993) Encapsulation of food ingredients. Crit Rev Food Sci Nutr, 33, 501-547

17. Krishnan S, Bhosale R, Singhal RS (2005) Microencapsulation of cardamom oleoresin: Evaluation of blends of gum arabic, maltodextrin and a modified starch as wall materials. Carbohydrate Polym, 61, 95-102

18. Cho YH, Shin DS, Park JY (1997) Microencapsulation technology in the food industry. Food Sci and Industry, 30, 98-111

19. Saha SK, Brewer CF (1994) Determination of the concentrations of oligosaccharides, complex type carbohydrates, and glycoproteins using the phenolsulfuric acid method. Carbohydr Res, 254, 157-167

20. Phillips RD, Chinnan MS, Branch AL, Miller J, Mcwatters KH (1998) Effects of pretreatment on functional and nutritional properties of cowpea meal. J Food Sci, 53, 805-809

21. Walstra P, Geur TJ, Noomen A, Jellema A, Van Boekel MSJS (1999) Dairy technology- principles of milk properties and processes. Marcel Dekker Inc., NC, USA, p 455-457

22. Dewanto V, Wu X, Adom KK, Liu RH (2002) Thermal processing enhances the nutritional value of tomatoes by increasing total antioxidant activity. J Agric Food Chem, 50, 3010-3014

23. Abdel-Hameed ESS (2009) Total phenolic contents and free radical scavenging activity of certain egyptian Ficus species leaf samples. Food Chem, 114, 1271-1277

24. Blois MS (1958) Antioxidant determination by the use of a stable free radical. Nature, 181, 1199-1200

25. Marklund S and Marklund G (1974) Involvement of the superoxide anion radical in the autoxidation of pyrogallol and convenient assay for superoxide dismutase. Eur $\mathbf{J}$ Biochem, 47, 469-474

26. Kim MS, An YJ, Lee JC, Park GR, Park DS, Jeon NG, Lee YJ, Han CH (2016) Hangover relieving effect of Sanghwang mushroom mycelium extract. Korean J Vet Res, 56, 241-247

27. Kang YC, Choi KK, Kim KH, Kim HK (2002) Microencapsulation of aster scaber and aster glehni by 
spray drying. Korean J Food Preserv, 9, 212-220

28. Park SJ, Hong JH, Youn KS, Choi YH (2006) Form manufacturing and quality characteristics using extracts from Hericium erinaceus. Korean J Food Preserv, 13, 569-573

29. Kim HR, Seog EJ, Lee JH, Rhim JH (2007) Physicochemical properties of onion powder as influenced by drying methods. J Korean Soc Food Sci Nutr, 36, 342-347

30. Moon JH, Kim RS, Choi HD, Kim YS (2010) Nutrient composition and physicochemical properties of korean taro flours according to cultivars. Korean J Food Sci Technol, 42, 613-619

31. Biliaderis CG, Swan RS, Arvanitoyannis I (1999) Physicochemical properties of commercial starch hydrolyzates in the frozen state. Food Chem, 64, 537-546

32. Kim JW, Park IK, Youn KS (2013) Phytochemical compounds and quality characteristics of spray-dried powders with the blanching condition and selected forming agents from pressed extracts of Ligularia fischeri leaves. Korean J Food Preserv, 20, 659-667

33. Han MW and Youn KS (2009) Quality characteristics of spray drying microparticulated calcium after wet-grinding. Korean J Food Sci Technol, 41, 657-661
34. Bae SJ (2010) Effects on manufacturing of persimmon powders by treatment of sulfite and maltodextrin. MS Thesis, Chonnam National University, Korea, p 51

35. Paik SYR, Ryu JN, Ko SH (2012) Comparison of physicochemical poperties of calcium carbonate nano-and micro-powders. Food Eng Prog, 16, 134-138

36. Lee SH, Hwang IG, Nho JW, Chang YD, Lee CH, Woo KS, Jeong HS (2009) Quality characteristics and antioxidant activity of Chrysanthemum indicum L.,Chrysanthemum boreale M. and Chrysanthemum zawadskii K. powdered teas. J Korean Soc Food Sci Nutr, $38,824-831$

37. Kim JW, Kwon YR, Youn KS (2012) Characteristics and antioxidant properties in spray-dried and freeze-dried powder prepared with powdered seaweed extracts. Korean J Food Sci Technol, 44, 716-721

38. Han DS, Kim SJ (1994) SOD-like compounds and development of functional food. Bull Food Technol, 7, 41-49

39. Hong CY, Kim JB, Noh HJ, Na CS (2015) Effects of dextrin and $\beta$-cyclodextrin on protective effect of Hovenia dulcis fruit extract against alcohol-induced liver damage in vivo, J Fd Hyg Safety, 30, 115-119 